\title{
Personundersøgelser mellem forskning og praksis - samarbejdets muligheder
}

\author{
Af Ph.d., postdoc, Louise Victoria Johansen ${ }^{1}$ og \\ direktør for Center for Straffuldbyrdelse, \\ Direktoratet for Kriminalforsorgen, Annette Esdorf ${ }^{2}$
}

\begin{abstract}
This article describes collaboration between research project and the Danish Department of Prisons and Probation in regard to the production and use of presentence reports. It highlights ways in which the conclusions reached in a recent $P h D$ thesis have contributed to an understanding of the legal frameworks and practices of both the Prosecution Service and the Probation Service. Until now, pre-sentence reports were requested for different reasons in different police districts. This led to broad discrepancies in the number and types of cases for which reports were issued. Local probation officers have also had different standards and practices for issuing reports. This situation affected the quality of the reports produced. The legal frameworks and practices of the Prosecution Service and the Probation Service have been revised at least partly on the basis of the PhD project's conclusions. The current article is written as a dialogue between the research and its application by the Department of Prisons and Probation. It concludes by discussing the advantages of applying research and considering the different agendas of research and practice.
\end{abstract}

\section{Introduktion}

Personundersøgelser efter retsplejelovens $\S 808$ bliver udfærdiget af Kriminalforsorgen i Frihed i straffesager, hvor anklagere eller forsvarere skønner, at en eventuel fængselsdom kan blive gjort helt eller delvist betinget med mulige vilkår om samfundstjeneste eller behandling. Personundersøgelserne skal forsyne retten med information om den sigtedes personlige og sociale omstændigheder samt om egnetheden til disse forskellige sanktionsmuligheder. Men i hvilke sager får sigtede i praksis udfærdiget en personundersøgelse, og hvilke kriterier anlægger

* Title in English: Pre-sentence reports between research and practice: Possibilities for collaboration. 
man herfor? Hvilken relation skabes der mellem den sigtedes baggrund og den begåede lovovertrædelse, og hvad mener forsvarerne egentlig, når de taler om »min klients gode, personlige forhold«? Disse spørgsmål dannede afsættet for Louise V. Johansens ph.d.-projekt om en praksis, som gennemgående forekommer de retlige aktører både ligetil og uproblematisk. Fra 2009 til 2012 udførte hun et antropologisk, kvalitativt studium af den rolle, som de retlige aktører tillægger sigtedes personlige forhold, herunder som de fremkommer gennem personundersøgelsen (Johansen 2012, 2015).

Selv om personundersøgelser kan have indflydelse på straffastsættelsen og helt grundlæggende bliver opfattet som et formildende indslag for sigtede, har hverken deres begæring, udfærdigelse eller betydning for dommernes beslutninger hidtil været genstand for en systematisk, samlet analyse. ${ }^{3}$ Dette står i modsætning til de mere omfattende studier af tilsvarende dokumenter og deres indflydelse på rettens forståelse af sagen og sigtede i andre lande i Europa (f.eks. Tata et al. 2008, Beyens \& Scheirs 2010, Phoenix 2010). De viser bl.a., at dommere er optagede af denne personlige, individuelle dimension ved straffastsættelsen, men også at de med skiftende held forsøger at »afkode« de oplysninger, som kriminalforsorgens ansatte har forsøgt at formidle i dokumentet. Det vil sige, at det personlige islæt faktisk anskues som væsentligt for at kunne dømme - og måske endda dømme mildere (jf. Balvig 2006). ${ }^{4}$ Samtidig virker formidlingen af personlige oplysninger gennem denne type undersøgelse mere kompliceret, end man måske har gjort sig klart i en dansk, retlig sammenhæng.

Direktoratet for Kriminalforsorgen og vicedirektør Annette Esdorf har støttet afhandlingens realisering gennem de fornødne tilladelser, faglig sparring og efterfølgende anvendelse af forskningsresultaterne. Nærværende artikel præsenterer det konkrete udkomme af vores udveksling og de muligheder for samarbejde, der ligger mellem forskere og praktikere med forskellige dagsordener og vidensbehov. Artiklen tager således udgangspunkt $\mathrm{i}$ to hovedpunkter fra afhandlingen, som vi særligt har haft en udveksling om. Det drejer sig for det første om indhentningen af personundersøgelser, som foregår uensartet fra retskreds til retskreds og dermed influerer på omfanget af foretagne undersøgelser, og for det andet om indholdet af personundersøgelserne, som er svingende pga. forskellig praksis i de lokale afdelinger af Kriminalforsorgen i Frihed (KiF).

Artiklen præsenterer ud fra hvert af de to temaer først forskningsresultaterne, og så de konkrete ændringer på området, som er sket siden afhandlingens indlevering 2012. 


\section{Afhandlingen: objekt, metoder og analytisk vinkel (Louise)}

Når anklagemyndigheden beslutter sig for at rejse en sag mod en borger, kan man i denne forbindelse tage stilling til, om den sigtede bør få foretaget en personundersøgelse. Hvis anklagerne ikke selv tager dette skridt, kan den sigtedes forsvarer bede om det. Anklagemyndigheden sender begæringen om en personunders $\varnothing-$ gelse til KiF, som tager kontakt til den sigtede. Det er frivilligt for den sigtede at deltage, men forsvarerne anskuer, lige som alle andre retlige aktører, at personundersøgelsen er en enorm fordel for den sigtede. Det er derfor meget få mennesker, som i praksis siger nej til en personundersøgelse, uanset om de benægter eller tilstår sagens forhold. Som oftest vil en honorarlønnet personundersøger foretage interviewet med den sigtede og derefter skrive en rapport på ca. 7 sider, heraf $1 \frac{1}{2}$ sides resume og konklusion, hvor KiF bl.a. tager stilling til, om den sigtede er egnet til at udføre samfundstjeneste eller har brug for behandling. Rapporten godkendes af ledelsen i den lokale KiF-afdeling og sendes med anklagemyndighedens mellemkomst videre til retten.

Under retsmødet vil de personlige forhold blive gennemgået lige inden anklagerens og forsvarerens afsluttende bemærkninger. De personlige forhold indbefatter både sigtedes straffeattest, som anklageren gennemgår, og den sigtedes sociale og personlige situation, som forsvareren fremlægger. Hvis en $§ 808$-undersøgelse foreligger, læser forsvareren normalt kun resume og konklusion op. Foreligger en undersøgelse ikke, stiller forsvareren den sigtede en række spørgsmål i retssalen, som dog begrænses af retssagens stramme tidsramme. Efter de sidste bemærkninger trækker dommerne sig tilbage til voteringsrummet, hvor de først afgør skyldsspørgsmålet og siden, under overvejelserne om en eventuel straf, tager stilling til personundersøgelsens anbefalinger. Det er denne bevægelse af $\S 808$-dokumentet, som afhandlingen rent empirisk har fulgt.

\section{Metoder}

For at komme bag om de formelle strafferetlige retningslinjer og finde ud af, hvordan de involverede parter handler $i$ praksis på de enkelte sager, har jeg taget udgangspunkt $\mathrm{i}$ deltagerobservation og kvalitative interviews som metode.

Den antropologiske fremgangsmåde har især deltagerobservation som metodisk arbejdsredskab for at komme så tæt som muligt på de mennesker og den sammenhæng, som man ønsker at forstå (bl.a. Clifford 1992, Okely 1992). Gennem sammenlagt et års feltarbejde mellem januar 2009 og december 2010 har jeg fulgt, hvordan personundersøgelsen konkret bliver udarbejdet i KiF, hvordan den anvendes af forsvarere og anklagere under selve retssagen, og endelig hvordan dommere fortolker og bruger undersøgelsen ved straffastsættelsen. På den måde 
har jeg søgt at opnå indsigt i deres daglige arbejde og rutiner, som ikke altid kan belyses ved at man spørger aktørerne selv, da de ikke nødvendigvis er opmærksomme på den betydning, som denne »hverdagspraksis« har i en bredere kontekst (jf. Bernard 1995). Jeg har derfor siddet på kontor med anklagerne, deltaget i 32 samtaler med forskellige sigtede $\mathrm{i} \mathrm{KiF}$, og jeg har fulgt de samme 32 sager, når dommerne behandlede dem i retten og til voteringen. Desuden er der udført semistrukturerede interviews med 57 informanter, herunder dommere, anklagere, forsvarere og ansatte i KiF.

Vejen til viden

Personundersøgelsens »karriere« gennem disse institutionelle sammenhænge har lagt op til et fokus på vidensprocesser som en gennemgående analytisk vinkel til at forstå den proces, hvorigennem sigtedes livshistorie bliver til. Bruno Latours $(1999,2008)$ Aktør-Netværks-Teori forklarer, hvordan mennesker handler inden for et netværk af interesser, hvor uregelmæssigheder kan påvirke de forskellige institutioners handlinger: Foreligger der f.eks. en $\S 808$ i en given sag, eller gør der ikke? Hvad ved man som dommer eller anklager om den sigtede, når man står i retssalen, og hvordan er man kommet frem til denne viden? Hvad bliver denne viden brugt til, og hvordan indvirker den på rettens forståelse af sagen og på straffastsættelsen? Svarene er ikke entydige, og derfor kan straffesystemet heller ikke ses som en institutionel maskine, der udelukkende producerer systematik. Anklagere, forsorgsmedarbejdere og dommere er tilknyttet institutioner, som er karakteriseret ved bestemte (omend vekslende) arbejdspladser, forskellige regulativer, arbejdsmål mm. Spørgsmålet er, hvilken indflydelse disse adskilte arbejdssteder har på de vidensprocesser, som er fokus for analysen, og hvordan grænsefladerne mellem institutionerne medvirker til at opretholde eller forhandle forskelle i kompetencer, viden og indflydelse. Denne viden er »situeret« og kontekstualiseret, forstået sådan, at det som aktørerne »ved « - eller »ikke ved « - er forbundet med en videnspraksis, som kan variere alt efter den institutionelle sammenhæng. Både anklagere og dommere vil i deres egenskab af jurister definere den juridiske relevans af en $\S 808$ ens, men de kan have forskellige opfattelser af den praksis, der bør være omkring indhentningen af den, samt den rolle, den bør spille ved straffastsættelsen.

Studiet belyser således det mulighedsrum, som undersøgelsen skaber for forståelsen af den sigtede. Der er derimod ikke tale om evaluering eller en effektmåling af $\S 808$-undersøgelserne, ligesom studiet ikke ser på den statistiske relation mellem f.eks. KiF's anbefalinger og de konkrete domme. 


\section{Del I. Omfanget af personundersøgelser i voldssager}

Det første punkt, som forskningsprojektet og Kriminalforsorgen har kunnet finde et interessefællesskab omkring, er praksis for indhentningen af personundersøgelser. Projektet har fokuseret på voldssager, primært omfattet af $\S 244$, men også $\S 119, \S 121, \S 245$, hvor en betinget eller delvist betinget dom, eventuelt med vilkår, må anses for at udgøre et muligt, men ikke oplagt udfald. Valget skyldes, at der på tidspunktet for mit feltarbejde var mindre klare retningslinjer for rekvirering af en $\S 808$ i voldssager end ved visse andre kriminalitetsformer. Det var antagelsen, at der derfor i voldssager er mulighed for flere »fortolkninger « af sigtedes situation, når man skal vurdere, om der hhv. bør indhentes, produceres og anvendes en $\S 808$ (jf. Tata et al. 2008:839). Desuden nødvendiggør den korte sagsbehandlingstid i voldssager, at anklagere må handle hurtigt, hvis der skal indhentes en $\S 808$-undersøgelse. ${ }^{5}$ Det har derfor vist sig, at der særligt i voldssager kan forekomme uensartet praksis, når anklagemyndigheden skal foretage dette skøn.

\section{Anklagernes rolle}

Af Meddelelse fra Rigsadvokaten 3/2000 om indhentning af personundersøgelser fremgik det indtil juli 2013, at anklagerne kunne begære en $\S 808$ i de tilfælde, hvor der kunne blive tale om en betinget dom med tilsyn, behandlingsvilkår eller samfundstjeneste under KiF. Omvendt burde anklagerne være varsomme med at bede om en $\S 808$ ved visse kriminalitetsformer og i tilfælde, hvor den sigtede var tidligere straffet for samme kriminalitet. Rigsadvokatens Meddelelse 3/2000 angiver derfor rammerne for det skøn, som anklagerne må udøve fra sag til sag. Det følgende uddrag af Rigsadvokatens Meddelelse definerer de retningslinjer, som anklagerne i praksis forholdt sig til på tidspunktet for mit feltarbejde i 2009-10 hvad angår voldssager:

"Samfundstjeneste ved kriminalitet som f.eks. vold, røveri, narkotikasager og sædelighedsforbrydelser bør stadig anvendes med varsomhed. Samfundstjeneste i disse sager [...] bør fortsat kun anvendes, hvis det efter en konkret, individuel vurdering findes forsvarligt.

I sager om f.eks. vold, røveri, narkotikasager og sædelighedsforbrydelser (varsomhedsområdet) skal personundersøgelse dog kun indhentes på anklagemyndighedens initiativ, hvis det efter en konkret individuel vurdering skønnes sandsynligt, at samfundstjeneste - eventuelt i kombination med en ubetinget straf - vil blive resultatet. [...]«

Meddelelsen bevæger sig mellem formuleringer om, hvad anklagerne skal, og hvad de efter en konkret, individuel vurdering skønner. Ligeledes bliver der opstillet en modsætning mellem den strafpåstand, som anklagerne selv vil nedlæg- 
ge, og den som de regner med kan blive udfaldet efter retspraksis, dvs. sådan som dommerne reelt dømmer. Denne sondring drejer sig om, at anklagerne har vold som varsomhedsområde og derfor oftest nedlægger påstand om en ubetinget straf, mens domstolene i førstegangstilfælde og ved mindre grov vold i en del sager giver en betinget dom, herunder f.eks. med vilkår om samfundstjeneste eller behandling. Rigsadvokatens Meddelelse er formuleret sådan, at den i praksis kan læses meget forskelligt, hvilket under mit feltarbejde viste sig i to forskellige politikredse, som havde ca. samme størrelse. I den ene kreds vægtede anklagerne den del af Rigsadvokatens Meddelelse, som betoner, at anklagerne bør indhente en undersøgelse, uagtet at de ikke selv finder en betinget dom tilstrækkelig. Jeg har efterfølgende selv observeret denne praksis i forbindelse med mange retsmøder i denne retskreds, hvor et flertal af anklagerne da også bekræftede, at $\S 808 \mathrm{i}$ førstegangssager om vold ofte blev indhentet af dem selv.

Denne måde at handle på $i$ forhold til indhentningen af en personundersøgelse var forskellig i den anden politikreds, idet anklagerne kontinuerligt henviste til vold som et varsomhedsområde, hvor de skal nedlægge påstand om en ubetinget straf. Denne kreds betoner altså en anden formulering i cirkulæret, og det gør de ud fra argumentet om, at de implicit formidler en sanktionspåstand ved at bede om en $\S 808$-undersøgelse:

Pernille, anklager: »Hvis jeg har en eller anden, som går ned her på vejen og slår en anden - jeg ville aldrig indhente en 808 , det ville være fuldstændig udelukket. Fordi, der ligger også noget signalværdi i, om jeg indhenter den undersøgelse.«

L.: »Signalværdi i forhold til hvem, tænker du?«

Pernille: »I forhold til retten. Hvis jeg, altså det er sådan jeg oplever det, hvis jeg indhenter en 808 på dem, så indikerer jeg allerede der, at resultatet måske kan gå i retning af en betinget dom, og det signal ønsker jeg ikke at sende.«

Der var bred enighed i denne kreds om, at hvis man som anklager beder om en $\S 808$, så har man allerede lagt op til en betinget dom. Anklagerne peger på, at det er dommerne, der kan opfatte det sådan:

Katrine: »Men det er også den tendens der ligger i 808, at »anklageren er med på en betinget«, når vi beder om den.«

L.: »Hvordan kommer det til udtryk i retten? Er det forsvareren, der henviser til det?«

Katrine: »Nej. Jeg ved det ikke, jeg tror det er dommeren, eller domsmændene ... I hvert fald, når dommeren går ind og siger, at det er relevant med en 808 , så er oddsene ret så store for en betinget dom, vil jeg sige.« 
Anklagerne tillægger altså undersøgelsen en signalværdi, som rækker ud over, hvad den formidler om den sigtedes personlige forhold og KiF's anbefalinger, idet anklagerne føler, at de indirekte kommunikerer sanktionsvalg med dommerne gennem dette dokument.

Det andet forhold, som gør, at anklagerne anskuer det som forsvarerens opgave at indhente undersøgelsen, er, at de tydeligt anser $\S 808$ for at være i forsvarerens interesse, hvilket de udtrykte ved at kalde dokumentet »et forsvarerværktøj«.

Endvidere understreger disse holdninger til $\S 808$-undersøgelsen, at anklagerne faktisk mener, at den spiller en ikke uvæsentlig rolle i forhold til dommernes straffastsættelse. Og det er dybest set også derfor, de ofte ikke indhenter den.

Anklagemyndighedens institutionelle retningslinjer kan således bringes i spil til at understøtte vidt forskellige handlemåder ift sigtede, således at man ud fra RM 3/2000 kan argumentere både for og imod indhentningen af en § 808 i ligeartede sager, og dermed det niveau af viden - eller ikke-viden - som den enkelte institution ønsker (jf. Douglas 1986). De institutionelle strukturer i form af bl.a. Rigsadvokatens Meddelelse udstikker et rum for praksis, men anklagere handler på dem i konkrete situationer med forskellige udfald til følge (Justesen 2008). Siden afhandlingens indlevering i 2012 er der sket ændringer i netop Rigsadvokatens Meddelelse, som har ændret praksis i forhold til indhentningen af $\S 808 \mathrm{i}$ voldssager. Mere grundlæggende sætter min analyse af muligheden for uensartet praksis omkring personundersøgelser dog fokus på den rolle, som parterne mener, dette dokument indtager under retssagen, og de interesser, det formidler. Mens rammerne for skønnet derfor nok er blevet begrænsede af ændringen i Meddelelsen, er det ikke utænkeligt, at anklagere og forsvarere stadig kæmper om personundersøgelsens betydning.

\section{Annettes kommentarer til Del I om omfanget af personundersøgelser i voldssager}

Louises ph.d.-afhandling afdækker, at der er en uensartet praksis i politikredsene for, hvornår der bliver indhentet personundersøgelse. De daværende retningslinjer fra Rigsadvokaten i Meddelelse 3/2000 om Personundersøgelser ved Kriminalforsorgen fortolkes forskelligt af anklagerne. Visse steder er man mere tilbageholdende med at indhente personundersøgelse i sager, hvor anklagemyndigheden vil argumentere for en ubetinget dom, fordi indhentelse af en PUS signalerer over for dommeren, at anklageren »er med på« en betinget dom.

Afhandlingen viser også, at der er almindelig enighed blandt alle retsvæsenets aktører om, at en personundersøgelse er »en chance for den sigtede til at opnå en mildere straf«. Derfor er det også en temmelig alvorlig kritik, at indhentelse af 
personundersøgelse varierer fra kreds til kreds, dvs. at nogen får en ekstra chance, mens andre »bare får taksten«.

Heldigvis er det sådan, at indholdet af den instruks i RA Medd. 3/2000, som ifølge afhandlingen fortolkes forskelligt, er blevet historie, siden Louises afhandling blev skrevet.

I flerårsaftalen med politikerne om Kriminalforsorgens økonomi for 20132016 var der blandt aftaleparterne enighed om at øge brugen af alternativer til frihedsstraf, og et af de initiativer, der skulle medvirke hertil, var en udvidet brug af personundersøgelser. Af Bilag 1 til aftalen fremgår således:

»Aftaleparterne er enige om at øge brugen af samfundstjeneste og fodlænke og indføre mulighed for udslusning med fodlænke mv. ved følgende initiativer:

Udvidet brug af personundersøgelser

Det gøres obligatorisk at tilvejebringe en personundersøgelse i alle straffesager mod personer på 18 år og derover, hvor sagen er eller vil blive indbragt for retten med påstand om indtil 1 år og 6 måneders fængsel.

Personundersøgelser vil dog fortsat ikke skulle tilvejebringes ved særligt grov, herunder professionel eller organiseret kriminalitet, som gør, at det efter praksis vil være udelukket, at der vil blive idømt andet end en ubetinget frihedsstraf. Endvidere skal personundersøgelse ikke som udgangspunkt tilvejebringes i sager, der forventes at medføre udvisning ved dom.

...«

Dette blev stadfæstet af Folketinget ved lov nr. 628 af 12. juni 2013 om ændring af straffeloven, lov om fuldbyrdelse af straf mv., hvor det i bemærkningerne til lovforslaget fremgår, at initiativet forudsættes gennemført administrativt.

Som konsekvens heraf blev Rigsadvokatens Meddelelse 3/2000 ændret med virkning fra 1. juli 2013. Under pkt. 4 om »Samfundstjeneste« fremgår det nu:

"4.1. Obligatorisk indhentelse af personundersøgelse i sager med påstand om fangsel i op til 1 år og 6 måneder

Det fremgår af forarbejderne til lov nr. 628 af 12. juni 2013 (lovforslag nr. L 133 af 31. januar 2013, de almindelige bemærkninger, pkt. 7), at brugen af samfundstjeneste skal øges gennem en mere systematisk tilvejebringelse af personundersøgelser, således at flere kan idømmes en betinget dom med vilkår om samfundstjeneste i stedet for en ubetinget fængselsstraf.

Det er derfor det klare udgangspunkt, at der altid skal indhentes en personundersøgelse med henblik på samfundstjeneste i straffesager, hvor den pågældende på gerningstidspunktet var fyldt 18 år, og hvor sagen er eller vil blive indbragt for retten med påstand om fængsel i 1 år og 6 måneder eller derunder.

Dette gælder dog ikke, hvis 
- den pågældende inden for de seneste 2 år regnet fra gerningstidspunktet er idømt en ubetinget frihedsstraf, herunder en kombinationsdom, for ligeartet kriminalitet,

- der er tale om særlig grov, herunder professionel eller organiseret kriminalitet, som indebærer, at det efter praksis vil være udelukket at idømme andet end en ubetinget fængselsstraf, eller

- der nedlægges påstand om ubetinget udvisning.

Personundersøgelsen skal indhentes, når ovennævnte betingelser er opfyldt, uanset om anklagemyndigheden i den konkrete sag påtænker at nedlægge påstand om en ubetinget frihedsstraf.

..."

Det er åbenbart, at skønnet i den nye bestemmelse er væsentligt indskrænket i forhold til den tidligere formulering, hvor personundersøgelse i sager inden for varsomhedsområdet, herunder i voldssager, kun skulle indhentes på anklagemyndighedens initiativ, hvis det efter en konkret individuel vurdering skønnes sandsynligt, at samfundstjeneste - evt. i kombination med en ubetinget straf - vil blive resultatet (min kursivering).

Effekten af den ændrede RA Meddelelse 3/2000

Så er det jo interessant at se, hvordan det er gået efter ændringen. Er der indhentet flere personundersøgelser? Og har det ført til flere domme med samfundstjeneste? Eller med andre ord: Har det initiativ, Folketinget vedtog, haft den ønskede effekt?

Og svaret er ja! At det har ført til flere personundersøgelser, er der ikke tvivl om. Antallet af udførte personundersøgelser i årene 2012-2014 ser ud som følger:

\begin{tabular}{lcc}
\hline Årstal & Gennemførte PUS & $\begin{array}{c}\text { Gennemførte PUS } \\
\text { med henblik på samfundstjeneste }\end{array}$ \\
\hline 2014 & 13.125 & 9.192 \\
2013 & 11.866 & 7.513 \\
2012 & 11.039 & 6.282 \\
\hline
\end{tabular}

For så vidt angår udviklingen $\mathrm{i}$ gennemførte personundersøgelser med henblik på samfundstjeneste er der sket en stigning på hele 46 procent fra 2012 til 2014. Tallene omfatter alle personundersøgelser, dvs. ikke særligt dem, hvor der påstås fængsel i op til 1 år og 6 måneder. Men der er ikke tvivl om, at ændringen af RM 3/2000 i midten af 2013 har været - i hvert fald stærkt medvirkende - årsag til den store stigning i det samlede antal personundersøgelser. 
Når man ser på udviklingen i antallet af domme til samfundstjeneste, er svaret ikke helt så enkelt. Tallene for domme til samfundstjeneste fremgår af tabellen nedenfor.

Antallet af samfundstjenestedomme i Danmark (ekskl. Grønland og Farøerne), 2008-2015

\begin{tabular}{lrrrrrrr|rrr}
\hline & 2008 & 2009 & 2010 & 2011 & 2012 & 2013 & 2014 & $\begin{array}{c}2014 \\
1 . \\
\text { halvår }\end{array}$ & $\begin{array}{c}2015 \\
\text { halvår }\end{array}$ & $\begin{array}{c}\text { Procent- } \\
\text { ændsing }\end{array}$ \\
\hline Vold & 876 & 872 & 810 & 778 & 751 & 670 & 738 & 356 & 535 & 50 \\
Narkotika & 155 & 152 & 164 & 162 & 151 & 173 & 239 & 110 & 151 & 37 \\
Røveri & 36 & 56 & 41 & 44 & 35 & 22 & 42 & 23 & 21 & -9 \\
Tyveri & 237 & 301 & 362 & 396 & 382 & 357 & 375 & 187 & 261 & 40 \\
Anden berigelse & 222 & 214 & 272 & 262 & 299 & 297 & 354 & 163 & 192 & 18 \\
Sædelighed & 16 & 12 & 21 & 21 & 20 & 15 & 36 & 18 & 13 & -28 \\
Færdselslov & 1.656 & 1.698 & 1.795 & 1.615 & 1.644 & 1.601 & 1.397 & 765 & 704 & -8 \\
Brugstyveri af & & & & & & & & & & \\
motorkøretøjer & 57 & 69 & 63 & 40 & 28 & 28 & 27 & 15 & 16 & 7 \\
Anden & & & & & & & & & & \\
kriminalitet & 273 & 295 & 356 & 418 & 409 & 455 & 440 & 238 & 230 & -3 \\
\hline & & & & & & & & & & \\
I alt & 3.528 & 3.669 & 3.884 & 3.736 & 3.719 & 3.618 & 3.648 & 1.875 & 2.123 & 13 \\
\hline
\end{tabular}

Kilde: Kriminalforsorgens ledelsesinformationssystem.

Som det ses, var der i perioden fra 2012-2014 faktisk et lille fald (2\%) i det samlede antal domme til samfundstjeneste. Men i samme periode var der et fald på $14 \%$ i antallet af ubetingede fængselsdomme. Der har således været en relativ stigning i domme til samfundstjeneste. Og ser man alene på første halvår 2015, hvor der har været et fald $\mathrm{i}$ antallet af ubetingede fængselsdomme på yderligere $17 \%$, så har der i det første halvår 2015 været en stigning i antallet af domme til samfundstjeneste på $13 \%$ sammenlignet med 1. halvår 2014. Ser man alene på antallet af domme for vold - som er det område, Louises afhandling særligt tager sigte på - er antallet steget med hele 50 \% i forste halvår 2015 sammenlignet med halvåret før.

Alt i alt må det på baggrund af tallene kunne konkluderes, at det øgede antal personundersøgelser har haft den ønskede effekt, nemlig at øge brugen af samfundstjeneste. 
Konklusionen understøttes af en beregning, Kriminalforsorgen har foretaget af, hvor mange fængselspladser, der er frigjort som følge af den øgede brug af alternativer til frihedsstraf (samfundstjeneste, fodlænke og tidligere udslusning med og uden fodlænke), der som nævnt tidligere var et led i flerårsaftalen for Kriminalforsorgen 2013-2016. Det var forudsat, at der løbende i perioden 2013-2016 ville blive frigjort flere og flere fængselspladser som følge af den øgede brug af alternativer, og at der samlet ville være frigjort 93 åbne fængselspladser på årsbasis, når frigørelsesinitiativerne i flerårsaftalen havde fuld effekt i 2016. Imidlertid er der allerede i 2014 frigjort 104 åbne fængselspladser på årsbasis.

Den øgede brug af alternativer til frihedsstraf er - sammen med en faldende tilgang af fængselsdomme og varetægtsfængslinger - medvirkende til, at Kriminalforsorgen for første gang i mange år har et overskud af fængselskapacitet. Aktuelt har vi således midlertidigt lukket ca. 420 pladser ud af en samlet kapacitet på knap 4.200 pladser.

\section{Del II. Personundersøgelsernes indhold (Louise)}

Det har ikke været afhandlingens formål at lave en direkte evaluering af personundersøgelserne, ${ }^{6}$ men jeg har været interesseret $i$ at studere, hvem der i praksis udfører undersøgelserne, hvilke forudsætninger de har for det, og ud fra hvilken systematik de skaber viden om sigtede.

Ligesom det var tilfældet med selve rekvireringen af $\S 808$ dokumentet, er dets udfærdigelse også præget af forskelle KiF afdelingerne imellem, og fra personundersøger til personundersøger. Forholdet mellem ensartethed i praksis og en hensyntagen til den unikke relation mellem undersøger og sigtede er central for KiFs håndtering af undersøgelserne og for den viden, der bliver formidlet rent sprogligt i undersøgelsen. KiFs skriftlige standarder for, hvordan undersøgelsen skal skrives, er dog ikke altid kompatibel med de meget forskelligartede oplysninger, hver samtale frembringer. I den endelige undersøgelse kan informationerne derfor virke så kortfattede, at de kræver en vis fortolkning: Hvad fortæller det f.eks. om sigtede, at man oplyser, at: »Han har 4 venner, der ikke er kendt for kriminalitet«? Eller at: »Han virker jævnt til normalt begavet, flink og rar, men umoden«? Denne underforståede viden hviler på implicitte normer for adfærd og livsstil, og et af afhandlingens formål har været at analysere kategoriseringen af de sigtede langs sociale og kulturelle skel.

Retningslinjer for udfordigelse af personundersøgelser

$»$ Vejledningen for personundersøgere ${ }^{7}$ er udarbejdet af Direktoratet for Kriminalforsorgen, indeholder 71 sider med 22 bilag og er det centrale officielle doku- 
ment i forhold til udarbejdelsen af en $\S$ 808-undersøgelse i KiF. Den gennemgår personundersøgelsens anvendelsesområder, de retlige rammer, og de sociale og etiske dimensioner ved samtalen med den sigtede. Vejledningen fastslår, at personundersøgelsens hovedformål er at finde ud af de personlige og sociale oplysninger om den sigtede, som kan have betydning for sanktionsspørgsmålet, samt at kunne udføre et senere forsorgsarbejde i den lokale afdeling, hvis den sigtede skulle blive dømt (2002:8).

Selv om personundersøgelser bliver udfærdiget med udgangspunkt i denne Vejledning, er der alligevel en stor variation i praksis omkring den, som bliver skabt i de forskellige lokale KiF afdelinger. Det har særlig betydning, at de almindelige personundersøgelser ikke bliver udført af KiFs egne sagsbehandlere, men af en gruppe honorarlønnede undersøgere. De kommer ind til KiF's lokale afdeling for at gennemføre samtalen med den sigtede, hvorefter de tager hjem og skriver undersøgelsen samt sender den elektronisk til afdelingen. Oftest møder de faste sagsbehandlere ikke den sigtede, og bedømmelsen af vedkommende hviler på den enkelte personundersøger.

\section{Oplaringen}

Undervisningen af nye personundersøgere er forskelligartet fra den ene lokale afdeling af KiF til den anden. Det skyldes først og fremmest adgang til ressourcer og afdelingens størrelse. Det sker ofte, at undersøgeren efter en ansættelsessamtale i KiF modtager »Vejledning for personundersøgere« til egen gennemlæsning. Denne fremgangsmåde betyder, at undersøgeren selv må finde sin stil og spørgeteknik i interviewsituationen, da der ikke gives vejledning i det. De første undersøgelser, som han eller hun afleverer, rettes grundigt igennem, og hvis de afspejler, at der er grundlæggende problemer i vedkommendes arbejde, tager man en samtale med undersøgeren. Det sker, at en undersøger efter et stykke tid ikke findes egnet til arbejdet. Alle undersøgelser bliver læst og rettet af en fast medarbejder; herefter skriver typisk lederen eller en fuldmægtig konklusionen.

Blandt nogle af undersøgerne medfører denne lidt spredte og meget korte introduktion en følelse af sårbarhed $\mathrm{i}$ et arbejde, som de ellers tager meget alvorligt og går ind i med stort engagement. Samtalen bringer dem meget tæt på sigtede, men uden faglig opbakning, sådan som denne undersøger formulerer det:

Undersøger: »Det er rigtigt vanskeligt at gå ind i et menneske, synes jeg, på så kort tid, og så gå ud igen. Jeg synes, det er nogle sårbare ting, som de er nødt til at svare på. Og jeg synes, jeg får en vældig god kontakt med dem tit, så jeg synes de åbner sig meget, og så er det vanskeligt at lukke dem ordentligt ned igen, og det er vanskeligt for mig bagefter at sidde med en indsigt, og 
ikke skal handle på den overhovedet. [...] Og så er der jo ingen som helst kollegial [...] sparring.« (Interview)

De undersøgere, der udtrykker bekymring, gør det, fordi de føler sig ladt alene med nogle væsentlige vurderinger $\mathrm{i}$ en sagsbehandling løsrevet fra KiFs øvrige kontekst. Evnen til at understøtte undersøgerne afhænger dog også af den enkelte afdelings praksis på dette område.

\section{Rekruttering}

Undersøgernes autonomi skabes gennem den løse tilknytning til de lokale afdelinger af KiF samt deres faglige heterogenitet og store forskel i alderssammensætningen i gruppen af undersøgere, alt efter hvilken lokal afdeling af KiF de er rekrutteret i. Det ene sted er det især studerende, der påtager sig arbejdet, mens en anden afdeling fortrinsvis har »efterlønnere«.

Den faglige bredde er også stor: socialrådgivere, jurister, tidligere ansatte ved ordensmagten, sygeplejersker, etnologer, psykologer, studerende til socialrådgiver eller til filmvidenskab m.fl. Der er altså tale om en heterogen gruppe, både uddannelses- og erfaringsmæssigt. ${ }^{8}$ Personundersøgerne imellem er der en klar fornemmelse af, at deres forskellige arbejdsmæssige baggrunde kan have en indflydelse på deres måde at udføre undersøgelser på:

Kvindelig socialrådgiver: »Jeg mener klart, at med min baggrund, der er jeg vant til at spørge mere, jeg kommer mere rundt i forhold, deres økonomi, deres boligforhold, og ser nogle sammenhænge der, som andre ikke gør ..."

Kvindelig sygeplejerske: »Det var meget tydeligt i starten, da jeg lavede undersøgelser, at jeg har en skoling i at se på baggrunden for, at de er blevet de mennesker, de er blevet. Så det kom mine personundersøgelser også til at bære meget præg af. Jeg lagde en enorm vægt på opvækstvilkårene, og var meget detaljeret omkring de forhold der, fordi det var tit de forhold, der var betegnende for, hvorfor de stod i den situation, de stod i i dag. Så det er egentlig mest det, jeg synes, jeg har med mig.«

Undersøgerne tillægger deres egen faglighed og erfaring en betydning i det konkrete arbejde med undersøgelserne. De anvender forskellige kompetencer, som er medvirkende til at præge personundersøgelsen i forskellig retning: Nogle spørger indgående til de sociale omstændigheder, andre fokuserer på sammenhænge mellem opvækst og nutiden. Selv om undersøgerens baggrund langt fra udelukker, at der bliver trukket på andre typer viden, så kan nogle problematikker ved sigtedes person hermed blive mere eksponeret end andre. Det sætter den individuelle samtale i fokus og mindsker institutionaliseringen, men gør også udkommet mere 
uforudsigeligt. Personundersøgernes mange faglige baggrunde er ikke et nyere fænomen og kan genkendes i hele 1900-tallets danske forsorgssystem (Johansen 2012:71-72), men det giver en tilfældighed i forhold til, hvilken faglig forståelse der bliver lagt ind i samtalen.

\section{Samtalen}

Undersøgerne skal sammenholde de generelle krav og kriterier, som KiF stiller til en sådan undersøgelse, med en specifik relation dem og sigtede imellem. De ved ofte meget lidt om den enkelte sigtede, før mødet går i gang, og de bliver derfor nødt til at trække på den forhåndsviden, de har om, hvilke typer sigtede de normalt møder til samtalerne. Samtidig er der mulighed for, at der opstår nye indtryk af den sigtede, efterhånden som samtalen forløber. Samtalen har derfor en lokal og personlig dimension, som i sig selv får nogle former for viden frem, som ikke ville kunne lade sig gøre uden dette møde. Her kan man afprøve forskellige mulige historier om den sigtede, inden man lægger sig fast på en bestemt viden om vedkommende og formidler det i dokumentets form (jf. Latour 1987:64-69).

Jeg anvender »kategorisering« af de sigtede som analytisk vinkel til at belyse, hvordan undersøgerne kan skabe viden om den sigtede i samtalesituationen:

»Der findes 3 typer [samtaler], sådan, vil jeg sige: I den første, der er de så dårlige, at man ikke vil genere dem med for mange spørgsmål. I den anden er de så velfungerende, at der ikke er behov for at gå i dybden, og i den sidste, det er der, hvor man undervejs finder noget, og graver ned i det, ja f.eks. at man finder et alkoholmisbrug ... Det er den gruppe, der tager rigtig meget tid!« (Gitte, undersøger)

Opdelingen af de sigtede i grupper, der kræver mere eller mindre opmærksomhed, er ikke ualmindelig blandt undersøgerne. De opfattelser er også genkendelige $\mathrm{i}$ et historisk perspektiv, hvor KiF flere gange har foreslået, at man godt kunne differentiere personundersøgelsernes grundighed alt efter, hvor »tunge« klienterne er. ${ }^{9}$ Dvs. at KiF arbejder med opfattelsen af nogle kategorier af sigtede, hvor der er relativt meget at finde, hvis man graver dybt, mens andre ikke kræver den grundighed. Følgende udsagn stammer f.eks. fra en observeret samtale, hvor undersøgeren efterfølgende forsøger at skabe overblik over informationerne og samtalen:

Undersøger: »Det bliver en noget begrænset undersøgelse, men der er jo heller ikke grund til at lede efter noget, hvor der ikke er noget. Det kan jo også være grænseoverskridende at spørge om alt for meget." 
Undersøgeren lægger op til, at det ikke bliver nødvendigt at gå så meget i detaljer med denne sigtedes liv. Vedkommende havde ekstraordinært gode, sociale forhold, og en dybdeboring i vedkommendes liv og barndom virker derfor ifølge undersøgeren unødvendig. Situationer, hvor man ifølge undersøgerne kan gå lettere hen over samtalen, peger dog også indirekte på en anden type samtaler, som undersøgerne anser for at være mere opmærksomhedskrævende. Det vil sige, at definitionen "velfungerende « som social kategorisering, sådan som den etableres både før og undersvejs i samtalen med den sigtede, kommer til at præge graden af »dybdeboring « $\mathrm{i}$ den sigtedes situation. Hermed påvirkes også det omfang, i hvilken undersøgeren »finder noget undervejs«, fordi der bliver gravet mere i de sigtedes situation, hvis undersøgeren har fået fornemmelsen af en risikoadfærd.

I analyser af dansk politi- og efterforskningsarbejde fremhæves det bl.a., at politiets opmærksomhed på »sædvanlige« lovovertrædere medfører, at politiet også finder relativt flere lovovertrædere ved at søge i bestemte sociale grupper frem for i andre (Holmberg 1999:232-233, Kyvsgaard 2001). Denne kategorisering kan udgøre en nødvendig arbejdsform i de situationer, hvor der gives begrænset tid til at foretage en vurdering. Konsekvensen er dog en social skævhed, fordi man kommer til at lede dér, hvor man er vant til at støde på problemer.

\section{Rapportens standard}

Undersøgerne lægger stort personligt og fagligt engagement i samtalen med sigtede, men hvor det individuelle møde med den sigtede går ud på at udforske relevant viden ud fra en række meget åbne parametre, udgør rapporten en langt mere bunden opgave. Helt grundlæggende skal alle oplysninger passes ind i de 7 afsnit, som skemaet består af, nemlig: 1. Opvækst og familieforhold; 2. Boligforhold; 3. Helbredsforhold; 4. Uddannelse, erhvervsforhold; 5. Økonomiske forhold; 6. Fremtiden/undersøgerens indtryk; og 7. Dokumentation/udtalelser.

De mange detaljer og oplysninger fra samtalen skal sprogligt set formuleres til korte afsnit inden for bestemte emneområder, hvorefter den lokale KiF-afdeling læser korrektur og godkender rapporten. KiF-afdelingerne arbejder for at øge ensartetheden i både form og indhold af rapporten. Det giver stabilitet og forudsigelighed i forhold til den type information, retten kan forvente at blive præsenteret for, og samtidig begrænses tilfældige oplysninger og forudindtagede meninger fra undersøgernes side. Standardiseringen har dog den konsekvens, at den specifikke viden om den sigtede og dennes livshistorie bliver sat ind $i$ en generaliseret vidensskabelon (jf. Hobart 1993, Scott 1998). Mange undersøgere føler f.eks., at de udførlige og individualiserede kommentarer, som de skriver i punkt 6 om »undersøgerens indtryk « af sigtede i samtalesituationen, bliver omformuleret af KiF- 
afdelingen til standardiserede udtryk såsom »Klienten svarede venligt og beredvilligt på spørgsmålene«. Efter nogen tids erfaring skriver undersøgerne derfor ofte ensartet under dette punkt, f.eks.:

»NN virkede i forbindelse med samtalen med undersøgeren samarbejdsvillig, imødekommende, positiv og venlig, og han medvirkede gerne til undersøgelsen.«

Rettelserne er kun grundige i den første tid, for »efterhånden ved jeg, hvad de vil have, der skal stå, og så skriver jeg det«, som en undersøger udtrykte det. Dvs. at der er mange standardformuleringer, man som undersøger lærer at kende af afdelingens praksis. Det er de vendinger, som nogle undersøgere kalder »fraser «. Den standardiserede sprogbrug skaber en type viden, som matcher den institutionelle forventning, men har svært ved at udtrykke de konkrete og mere personlige beskrivelser af den sigtedes forhold.

\section{Paradokserne}

Adgangen til meget personlig information om sigtede gennem samtalen giver nogle undersøgere et dilemma: de vil gerne formidle den information og den relation, de har opnået gennem samtalen, og det forsøges gjort inden for de institutionelle rammer. Dette skaber ind imellem nogle bemærkelsesværdige tekster. Gennem forventningen til undersøgerne om at overholde de faste vendinger og beskrivelser bliver der rent informationsmæssigt skabt paradokser, som modsiger standarden. Jeg refererer i det følgende til tre undersøgeres beskrivelse af deres indtryk af tre sigtede, som de kommer til at stå i resumeet i rapporten:

»Under samtalen med undersøgeren virkede AA imødekommende, samarbejdsvillig, stejl og egenrådig. Han var let at komme i kontakt med.«

»FF virkede under samtalen med undersøgeren smilende, selvstændig og selvsikker, men tilbageholdende, og han talte lavt og mindre tydeligt. Han var let at komme i kontakt med.«

»NN deltog villigt i samtalen. Han virkede noget forbeholden til en start og fortsatte med at være noget reserveret og kølig. Han var samarbejdsvillig, og svarede kort og præcist. Han var nogenlunde let at komme i kontakt med.«

Selv om teksten anvender de forventede, standardiserede vendinger om at være imødekommende, samarbejdsvillig og let at komme i kontakt med, indeholder den samtidig andre oplysninger, som virker modsatrettede. Samtalen, som den blev opfattet af undersøgeren, bliver kun delvist tilpasset KiF-standarden. Disse paradokser kan være vanskelige at forstå i retssalen, fordi man bliver i tvivl om, hvilket budskab der bedst karakteriserer den sigtede. De peger også på de mange 
uudtalte eller uigennemskuelige vurderinger, der foretages undervejs i hver sag omkring sigtedes personlige og sociale situation.

Den sociale kategorisering

Som nævnt kan det observeres både under samtalerne og i de endelige rapporter, at der formidles oplysninger om sigtedes barndom, voksenliv, økonomi og personlighed, som fortæller mere end oplysningerne umiddelbart indeholder. Der nævnes f.eks. detaljer om sigtedes opvækst, såsom forældrenes uddannelse og beskæftigelse, deres status som samboende og ægtefæller, mulige skilsmisser, flytninger, skoleskift mm. Oplysningerne ligger i forlængelse af, hvad både de enkelte KiF afdelinger og »Vejledning for Personundersøgere « (2002) betragter som væsentlig information om sigtede, men de afspejler også indirekte en social norm for opvækst og livsforløb, som de retlige aktører forsøger at afkode. F.eks. var der blandt rettens aktører en udbredt holdning om, at hvis sigtede havde skiftet skole mange gange, kunne det være tegn på »en ubehandlet ADHD«, som de udtrykte det. Denne sammenhæng bliver slet ikke beskrevet i rapporten, men bliver skabt gennem anvendelsen af den. Den sociale kategorisering, som forekommer implicit i personundersøgelserne, er således også virksom, fordi aftagerne mener at vide, hvilken værdi og hvilket indhold de forskellige oplysninger har. Denne »medproduktion« sker, fordi personundersøgelsen bygger på idealer for opvækst og livshistorieforløb, som vidner om bestemte sociale værdier.

En mulig forbedring af Kriminalforsorgens personundersøgelser, sådan som det vil blive diskuteret nedenfor, handler om at skabe ensartethed i forhold til både indhentningen og det endelige produkt. Mit argument er dog, at det er lige så væsentligt at arbejde for en synliggørelse af de implicitte normer og forhåndsantagelser, som ligger som mulighed i både samtalen, rapporten og dens anvendelse.

\section{Annettes kommentarer til Del II om personundersøgelsernes indhold}

Som praktiker med ansvar for et område er det jo ikke det sjoveste at blive konfronteret med forskning, som viser, at ting på området ikke fungerer tilfredsstillende. Kriminalforsorgen har ansvar for at udarbejde personundersøgelser, og det, der dokumenteres klart i Louises ph.d-afhandling, er, at indholdet i undersøgelserne varierer fra afdeling til afdeling, og at brugerne, herunder navnlig dommere, har en række ønsker om ændring af undersøgelserne.

I stedet for - som man godt kan være fristet til - straks at gå i forsvarsposition så valgte vi $\mathrm{i}$ Kriminalforsorgen at samarbejde med Louise og bruge den kritik fra brugerne, der afdækkes i rapporten, konstruktivt i et arbejde, vi har været i gang 
med et stykke tid. Et arbejde, der har som mål at forbedre og ensrette personundersøgelserne.

De fleste personundersøgelser udarbejdes af et korps af honorarlønnede undersøgere, som har meget forskellige faglige baggrunde, og disse forskellige baggrunde afspejler sig i resultatet af undersøgelserne. Det påvises også i afhandlingen, at der er store forskelle fra afdeling til afdeling, når det gælder oplæring af de honorarlønnede undersøgere. Nogle steder gives en egentlig undervisning, andre steder kun en kort/spredt information, og en del af de interviewede personundersøgere giver da også udtryk for nogen usikkerhed over for opgaven og efterlyser mere undervisning og kollegial sparring. Endvidere påvises uensartethed $\mathrm{i}$ vurderingen af »egnethed «, som i praksis er en vurdering, der foretages af det faste personale i KIF-afdelingerne, typisk af lederen eller fuldmægtigen.

Når der er almindelig enighed blandt aktørerne i retssystemet om, at personundersøgelser har indflydelse på valget af straffen, så er det klart, at vilkårlighed i indholdet og kvaliteten af personundersøgelserne - ligesom i tilbøjeligheden til at indhente personundersøgelser - også er en alvorlig kritik, da det vil indebære vilkårlighed i forhold til, hvem der får en mildere straf, og hvem der »bare får taksten«.

Afhandlingen beskæftiger sig en del med den vanskelige balance for undersøgerne, der ligger i, at de på den ene side ønsker, at den sigtede skal få så mild en dom som muligt - »alle skal have en chance/hellere en for mange end en for lidt" - og på den anden side skal kunne forsvare deres faglighed, legitimitet og troværdighed.

Som nævnt har vi i Kriminalforsorgen valgt at bruge Louises afhandling positivt $i$ vores igangværende arbejde med at forbedre indhold og kvalitet af personundersøgelserne. At se den som den nødvendige »brugerundersøgelse«, vi ellers selv havde måttet bruge tid og penge på.

Det er glædeligt at konstatere, at personundersøgelserne tilsyneladende nyder stor troværdighed hos dommerne, og at den generelle holdning blandt dommerne er, at kvaliteten af undersøgelserne er høj (Johansen 2012:117). Der udtrykkes blandt de interviewede dommere tilfredshed med, at undersøgelserne er grundige og strukturerede, men de finder også en del overflødige oplysninger i resuméerne. »Lad os få det relevante og kun det«, som en dommer udtrykker det.

Hvad har vi så gjort for at imødekomme kritikken og for at højne kvaliteten af undersøgelserne?

1. Vi har i 2013 etableret et landsdækkende netværk for personundersøgelsesansvarlige. Netværket består af 2-3 erfarne medarbejdere fra hver KIF- 
afdeling, herunder kriminalforsorgsledere, der har til opgave at oplære og videreuddanne personundersøgere og sikre en fælles faglig standard i personundersøgelserne. Netværket bruges endvidere til faglig sparring, erfarings- og idéudveksling og er en værdifuld platform i arbejdet med udmøntning af lovændringer og centrale beslutninger. Netværket har indtil nu holdt 2 seminarer, og målsætningen er halvårlige seminarer.

2. Vi har holdt nogle seminarer med ledelserne af KiF-afdelingerne, hvor vi har arbejdet med at ensrette egnethedsvurderingerne og sikre en fælles grad af »risikovillighed «.

3. Til at understøtte arbejdet med oplæring af personundersøgere og understøtte en vis standard og lighed i undersøgelsesarbejdet har Kriminalforsorgen udarbejdet en ny »Håndbog for Personundersogere «. Denne indeholder blandt andet koncepter, understøttende værktøjer til brug for samtalen samt udarbejdelse af undersøgelsen, konklusioner, eksempler på forskellige typer af personundersøgelser (f.eks. samfundstjeneste, betinget dom, under 18 år mv.).

4. For at målrette og ensarte personundersøgelserne har Kriminalforsorgen endvidere udarbejdet et nyt personundersøgelsesskema. I det nye skema har vi forsøgt at imødekomme dommernes (»brugernes«) ønsker om at undgå overflødige oplysninger, få bedre begrundelser, kortere resuméer, ensartede konklusioner mv. Så »alt relevant, men kun det« kommer med, i hvert fald i resuméerne. Personundersøgelserne som sådan vil formentlig altid indeholde flere oplysninger end dem, der er relevante for dommerne i deres valg af sanktion. Det skyldes, at personundersøgelser har en anden vigtig funktion for Kriminalforsorgen, nemlig at udgøre forarbejdet til et eventuelt efterfølgende tilsynsarbejde.

Initiativerne nævnt under 3 og 4 har desværre ikke kunnet tages i brug endnu, fordi etablering af den nødvendige IT-understøttelse har været forsinket som følge af en omfattende ændring af Kriminalforsorgens struktur pr. maj 2015. Vi forventer, at ibrugtagning kan ske i november $i$ år.

\section{Konklusion}

Annette: De ændringer, der er sket omkring personundersøgelser siden Louises ph.d-afhandling, har haft til formål

- At få flere i samfundstjeneste

- At målrette personundersøgelserne

- At få mere ensartede personundersøgelser og konklusioner 
- At få større retssikkerhed for de sigtede

Afhandlingen har været et nyttigt redskab til at understøtte disse ændringer, fordi den har vist, hvordan forskelle i praksis kan opstå. Som praktiker er det glædeligt, at man kan bruge forskningen konstruktivt. Det tætte parløb, vi har haft omkring ph.d.-afhandlingen, er en »win-win«, som kun kan anbefales andre.

Noget, Kriminalforsorgen derimod ikke vil ændre på, er den overordnede holdning, som ifølge afhandlingen eksisterer i KIF, at flest muligt skal erklæres egnede: »hellere en for mange end en for lidt «. Kriminalforsorgens opgave er at gennemføre straffene på en måde, så flest muligt bliver resocialiseret - og her har samfundstjeneste åbenbare fordele frem for ubetinget fængsel. Kriminalforsorgens seneste recidivundersøgelse viser, at $37 \%$ af dem, der blev løsladt fra fængsel i 2012, recidiverede til ny kriminalitet inden for en 2-årsperiode, mens det kun gjaldt $18 \%$ af dem, der i 2012 blev idømt samfundstjeneste. Og kun en lille del i hvert fald under $10 \%$ - af dem, som er idømt samfundstjeneste, bliver indberettet for ny kriminalitet eller manglende overholdelse af vilkåret om samfundstjeneste. $^{10}$

De generalpræventive hensyn og hensynet til retshåndhævelsen er noget, dommerne skal varetage. Men de, som ikke erklæres egnede til samfundstjeneste, vil blive valgt fra allerede af den grund. I praksis er det meget sjældent (heldigvis!), at en dommer idømmer samfundstjeneste til en person, som i personundersøgelsen er vurderet ikke-egnet. Så længe langt de fleste dømte - over $90 \%$ gennemfører deres samfundstjeneste, bør vi i Kriminalforsorgen derfor holde fast i princippet: »hellere en for mange end en for lidt «.

Louise: Samarbejdet med Kriminalforsorgen om resultaterne af afhandlingen er i virkeligheden meget privilegeret. Som forsker er det ikke altid, man kan opleve så konkret et udkomme af et akademisk arbejde, endsige så stor lydhørhed fra praktikerens side. En vis nervøsitet har man også for, hvordan ens data kan blive brugt og med hvilke dagsordener for øje. Her har vi grundlæggende været enige om at ønske flere og bedre personundersøgelser, og det mål er tæt på. Er afhandlingens pointer så opfyldt og dermed overflødiggjort? Heldigvis ikke. Langt fra alle teoretiske aspekter ved et forskningsprojekt er relevante for praktikeren, men indføjer sig i en mere akademisk diskussion. Desuden er en af de væsentligste pointer i ph.d.-afhandlingen, at sigtedes personlige forhold, som de inddrages i retsprocessen, er præget af en bestemt forståelse af livsforløb og sociale værdier. Spørgsmålene om, hvad »gode, personlige forhold« egentlig dækker over, hvordan de defineres af personundersøgere såvel som retlige aktører, og hvilke sigtede 
der ikke opfylder disse kriterier, er helt centrale for afhandlingen, men mere perifere for Kriminalforsorgen. Grænserne for samarbejdet og de fælles interesser mellem forskning og praksis ligger måske der, hvor praktikerens beslutninger er påvirket af overordnede retningslinjer, der har til hensigt at definere værdigrundlaget for arbejdet (jf. Canton \& Yates 2008:14). En mere grundlæggende diskussion af, hvordan personundersøgelser i højere grad ville kunne udtrykke en social og kulturel diversitet blandt sigtede, afventer derfor og kunne være mål for fremtidigt samarbejde.

\section{Noter}

1. Louise Victoria Johansen er kandidat $i$ antropologi. Hun har siden opnået den juridiske ph.d.-grad fra Det Juridiske Fakultet, Københavns Universitet, hvor hun er ansat som postdoc med forskningsprojektet »Mellem jura og sund fornuft«: Domsmænds rolle i danske straffesager.

2. Annette Esdorf har arbejdet i Kriminalforsorgen siden 1979, de seneste 17 år som vicedirektør med ansvar for regler, standarder og praksis for behandlingen af frihedsberøvede $\mathrm{i}$ fængsler og arresthuse og klienter under tilsyn af Kriminalforsorgen i frihed. Siden en større ændring af Kriminalforsorgens organisation i efteråret 2014 har hun været direktør for Center for Straffuldbyrdelse i Direktoratet for Kriminalforsorgen.

3. Se dog Clausen 2007.

4. I et studium af den danske befolknings syn på straf (Balvig 2006) fremgik det, at et større kendskab til sigtedes person har indflydelse på danskeres valg af straf. Jo flere oplysninger folk får om sagen og den sigtede, jo mindre tilbøjelige er de til at pege på en ubetinget frihedsstraf. På baggrund af denne undersøgelse anbefalede man blandt ét ud af ni forslag til »bedre straf«, at der burde indhentes personundersøgelser i alle straffesager.

5. Politiet må være 30 dage om at efterforske sagen, og retten bør efterfølgende afgøre sagen inden for 37 dage.

6. Gennemgående nyder både personundersøgelserne og KiF stor respekt hos dommerne. Selv om dommerne har mulighed for at spørge den sigtede om vedkommendes personlige forhold i retssalen, foretrækker de, at KiF leverer en grundigere viden, særligt angående vilkår. § 808-dokumentet bliver særligt relevant for dommerne i de tilfælde, hvor de efter eget udsagn er i tvivl om sagen og sanktionen. Jo større tvivl eller gråzone man er inde i, jo større rolle kan dokumentet potentielt spille.

7. Versionen fra 2002 var virksom under mit feltarbejde.

8. Normalt angiver personundersøgelsen ikke den enkelte undersøgers faglige baggrund.

9. Jf. Straffelovskommissionens betænkning $\mathrm{nr}$. 82/1953 om forsorgsdomme og betingede domme samt Retningslinjer for etablering og gennemførelse af en forsøgsordning vedrørende samfundstjeneste omfattende hele landet, 1984, Direktoratet for Kriminalforsorgen.

10. Justitsministeriets Forskningskontor »Vilkårsovertrcedelser $i$ forbindelse med betingede domme«, august 2013. 


\section{Litteratur}

Balvig, Flemming. 2006. Danskernes syn på straf. København: Advokatsamfundet.

Bernard, Harvey Russell. 1995. Research Methods in Anthropology: Qualitative and Quantitative Approaches. Walnut Creek: AltaMira.

Beyens, Kristel \& Veerle Scheirs. 2010. »Encounters of a Different Kind: Social Inquiry and Sentencing in Belgium. « Punishment \& Society 12(3):309-28.

Canton, Rob \& Joe Yates. 2008. Applied Criminology. I B. Stout, J. Yates \& B. Williams (eds.) Applied Criminology. London: Sage.

Clausen, Susanne. 2007. Samfundstjeneste - virker det? En proces - og effektevaluering af samfundstjenesteordningen i Danmark. København: Københavns Universitet.

Clifford, James. 1992 »Traveling cultures.« in Cultural Studies, edited by L. Grossberg, C. Nelson and P. Treichler. New York \& London: Routledge.

Douglas, Mary. 1986. How institutions think. Syracuse, N.Y.: Syracuse University Press.

Hobart, Mark. 1993. »Introduction: The Growth of Ignorance?« in An Anthropological Critique of Development: The Growth of Ignorance, edited by Mark Hobart. London: Routledge.

Holmberg, Lars. 1999. Politiets skøn i retssociologisk belysning. Ph.d.-afhandling, Det juridiske Fakultet. Københavns Universitet.

Johansen, Louise Victoria. 2012. Livshistorier i straffesagen. Vidensprocesser om sigtedes person. Ph.d. afhandling, København: Det Juridiske Fakultet.

Johansen, Louise Victoria. 2015. Personen bag straffen. Forhandlingen af viden om sigtede. København: Djøf.

Justesen, Lise. 2008. Kunsten at skrive revisionsrapporter. En beretning om forvaltningsrevisionens beretninger. Ph.d.-afhandling. Copenhagen Business School.

Kyvsgaard, Britta. 2001. Kriminalitet, retshåndhævelse og etniske minoriteter. Juristen 9:363-73.

Latour, Bruno. 1987. Science in Action: How to Follow Scientists and Engineers through Society. Milton Keynes: Open University Press.

Latour, Bruno. 1999. Pandora's Hope, Essays on The Reality of Science Studies Cambridge: Harvard University Press.

Latour, Bruno. 2008. En ny sociologi for et nyt samfund. Introduktion til Aktør-Netvcerk-Teori. København: Akademisk Forlag.

Okely, Judith. 1992. »Anthropology and autobiography: participatory experience and embodied knowledge.« in Anthropology and Autobiography, edited by Judith Okely and Helen Callaway. New York \& London: Routledge.

Phoenix, Jo. 2010. Pre-Sentence Reports, Magisterial Discourse and Agency in the Youth Courts in England and Wales. Punishment \& Society 12(3):348-66.

Scott, James C. 1998. Seeing Like a State: How Certain Schemes to Improve the Human Condition Have Failed. New Haven and London: Yale University Press.

Tata, Cyrus \& Nicola Burns, Simon Halliday, Neil Hutton, Fergus McNeill. 2008. »Assisting and Advising the Sentencing Decision Process: The Pursuit of »Quality« in Pre-Sentence Reports. « British Journal of Criminology 48:835-55.

Justitsministeriets Forskningskontor. »vilkårsovertrcedelser i forbindelse med betingede domme«, august 2013

Kriminalforsorgens »Statistik 2014«. 